\title{
Corrigendum
}

\section{Corrigendum to "The Effect of Adipose-Derived Stem Cells on Wound Healing: Comparison of Methods of Application"}

\author{
Hyeonwoo Kim (D), Mi Ri Hyun, and Sang Wha Kim \\ Department of Plastic and Reconstructive Surgery, College of Medicine, Seoul National University, Seoul, Republic of Korea \\ Correspondence should be addressed to Sang Wha Kim; sw1215@snu.ac.kr
}

Received 15 January 2020; Accepted 16 January 2020; Published 8 April 2020

Copyright ( $\odot 2020$ Hyeonwoo Kim et al. This is an open access article distributed under the Creative Commons Attribution License, which permits unrestricted use, distribution, and reproduction in any medium, provided the original work is properly cited.

In the article titled "The Effect of Adipose-Derived Stem Cells on Wound Healing: Comparison of Methods of Application" [1], the affiliation should be changed from "Department of Plastic and Reconstructive Surgery, Seoul National University Hospital, Seoul, Republic of Korea" to the correct affiliation "Department of Plastic and Reconstructive Surgery, College of Medicine, Seoul National University, Seoul, Republic of Korea." The corrected affiliation is shown in the author information above.

\section{References}

[1] H. Kim, M. R. Hynn, and S. W. Kim, "The effect of adiposederived stem cells on wound healing: comparison of methods of application," Stem Cells International, vol. 2019, Article ID 2745640, 8 pages, 2019. 